\title{
Spawning seasons of Rasbora tawarensis (Pisces: Cyprinidae) in Lake Laut Tawar, Aceh Province, Indonesia
}

\author{
ZA Muchlisin1,2, Musri Musman4 and MN Siti Azizah*1,3
}

\begin{abstract}
Background: Rasbora tawarensis is an endemic freshwater fish in Lake Laut Tawar, Aceh Province, Indonesia. Unfortunately, its status is regarded as critical endangered with populations decreasing in recent years. To date no information on the spawning activities of the fish are available. Therefore, this study provides a contribution to the knowledge on reproductive biology of $R$. tawarensis especially on spawning seasons as well as basic information for conservation of the species.

Methods: Monthly sampling was conducted from April 2008 to March 2009 by using selective gillnets. The gonadosomatic index, size composition and sex ratio were assessed. The gonadal development was evaluated based on macroscopic and microscopic examinations of the gonads.

Results: The gonadosomatic index (GSI) varied between 6.65 to 18.16 in female and 4.94 to 8.56 for male. GSI of the female R. tawarensis was higher in March, September and December indicating the onset of reproductive seasons, the GSI and oocyte size being directly correlated with gonadal development stages. Although, a greater proportion of mature male than female was detected during the study, the sex ratio showed that the overall number of female was higher than male. The ovaries had multiple oocyte size classes at every stage of gonadal development, thus R. tawarensis can be classified as a group synchronous spawner or a fractional multiple spawner.

Conclusion: The spawning seasons of $R$. tawarensis were three times a year and September being the peak of the reproductive season and the female was the predominant sex. This species is classified as a group synchronous spawner.
\end{abstract}

\section{Background}

Rasbora tawarensis is an endemic freshwater fish in Lake Laut Tawar. It is one of the major freshwater fish, the main target for fishing in the lake and of considerable commercial importance in the region. It is listed in the IUCN red list as vulnerable [1] and updated by CBSG as critically endangered due to the very restricted area of its distribution [2]. Presently, the $R$. tawarensis population is decreasing, indicated by decreasing catch-per-unit effort (CPUE), where the average CPUE decreased from 1.17 $\mathrm{kg} / \mathrm{m}^{2}$ of net in the 1970 s to only $0.02 \mathrm{~kg} / \mathrm{m}^{2}$ of net in 2009 (Muchlisin, unpublished data). Unfortunately, many basic

\footnotetext{
*Correspondence: sazizah@usm.my

1 School of Biological Sciences Universiti Sains Malaysia, Penang 11800 Malaysia

Full list of author information is available at the end of the article
}

life history characteristics of the $R$. tawarensis have not been documented.

Studies on reproductive behaviour of fish are important and a basic requirement for improvement and effective fishery resources management and conservation [3-7], determination of basic life-history information and for assessing the impacts of environmental variability on the dynamics of fish populations [8]. Life history parameters such as spawning frequency and sex ratio may vary between populations of a species and temporally within population [9]. Several studies describing various aspects of reproductive biology have been conducted for many freshwater tropical cyprinids for example the snakeskin gouramy, Trichogaster pectoralis [10], Thynnichthys thynoides [3], snakehead, Channa striata [11], rainbow selebensis, Telmatherina celebensis [12], bonti-bonti, 
Paratherina striata [13] and serandang, Channa pleurophthalmus [14] and However, to date there has been limited study done on $R$. tawarensis despite its enormous fishery and ecological importance. Hence, the objective of the present study was to evaluate the spawning periodicity and sex ratio of $R$. tawarensis.

\section{Methods}

\section{Site and sampling technique}

Lake Laut Tawar $\left(04^{\circ} 36^{\prime} 43^{\prime \prime} \mathrm{N} 096^{\circ} 55^{\prime} 25^{\prime \prime} \mathrm{E}\right)$ is situated in Aceh Tengah, Aceh Province, Indonesia. It is located approximately $1,200 \mathrm{~m}$ above sea level. The lake is an old volcanic caldera of circa $16 \mathrm{~km}$ length, $5 \mathrm{~km}$ width and maximum predicted depth of $80 \mathrm{~m}$. It is surrounded by mountains reaching over 2000 meters. At least 25 short tributaries discharge into Lake Laut Tawar, the main outflow is Peusangang River. The watershed is covered by forests, which are increasingly affected by deforestation and agricultural activities.

Samplings were conducted from April 2008 to March 2009 using selective gillnet (mesh size 5/9 inch, $1.5 \mathrm{~m}$ depth and $20 \mathrm{~m}$ length). The gill nets were set up for eleven hours (18.00 PM to $05.00 \mathrm{AM}$ ) and every sampling trip was for two days. Collected fishes were counted, rinsed and anesthetized in a solution of tricaine methanesulfonate (MS 222), prepared by dissolving $4 \mathrm{~g}$ of MS 222 in $5 \mathrm{~L}$ tap water, then after preserved in $10 \%$ formalin in a plastic bag. The plastic bag was tagged by catching location, date and name of fish. The fish samples were transported to the laboratory for further evaluation.

\section{Gonadosomatic index (GSI) and gonadal development stages}

Specimens were measured to the nearest $\mathrm{mm}$ (total length-TL and standard length-SL) using a digital balance (Toledo, AB-204. Error $=0.01 \mathrm{~g}$ ), and weighed to the nearest gram by using a pair of digital callipers (Mitutoyo, CD-6CS. Error $=0.01 \mathrm{~mm}$ ). The gonads were removed by abdominal dissection and weighed to the nearest gram. The GSI was calculated using the formula below $[15,16]$ :

$$
\mathrm{GSI}=(\mathrm{GW} /(\mathrm{BW}-\mathrm{GW}) \times 100)
$$

where GSI is gonadosomatic index, GW is gonad weight $(\mathrm{g})$ and $\mathrm{BW}$ is total body weight $(\mathrm{g})$ with intact gonad.

Gonad development stage was determined and classified based on macroscopic and microscopic characteristics of the gonad modified from West [17] and Marcano [18]; i.e. immature, developing, mature, ripe and spent. Representative gonads were randomly taken from each stage of gonadal development to measure diameter of oocytes. At least 50 oocyte samples from anterior, middle and posterior of the ovary were measured by using a ste- reo microscope CCD camera. The oocyte size was calculated by using the formula: length axis plus wide axis divided by two.

\section{Histological procedure}

Samples of the central portion of the gonads of $0.5 \mathrm{~cm}$ thickness were washed, dehydrated in an increasing ethanol series, n-butilic alcohol, embedded in paraffin and sectioned for 7-10 $\mu \mathrm{m}$ in thickness using a microtome (Reichert-Jung 820, Germany). The sections were stretched in a water bath $\left(40^{\circ} \mathrm{C}\right)$ of distilled water. Three replicate section samples were gathered with the object glass properly labelled and dried for 24 hours at $37^{\circ} \mathrm{C}$ followed by one hour at $60^{\circ} \mathrm{C}$ over a stove. Sections were stained with a solution of Ehrlich hematoxilline and eosine for a general assessment of the histological components of the gonads.

\section{Data analysis}

The data were subjected to an analysis of variance (ANOVA), followed by comparison of means using Duncan's multiple range test to determine significance of each data treatment [19]. All statistical analyses were performed using SPSS v14.

The linear regression and correlation analyses were utilized to describe relationships between GSI and total length or body weight, GSI and proportion of mature female, while the power regression was performed to describe the relationship between spawning frequency and proportion of mature females.

\section{Results}

\section{Gonadal development and spawning season}

Based on macroscopic and microscopic evaluation, the gonadal development stages of $R$. tawarensis were divided into 5 classes (Table 1). A least two developmental stages of oocytes were present in the ovary (Figure 1). Fish with gonad stages III and IV were considered sexually mature. In general, all stages of gonads were observed in every monthly sampling, where a higher proportion of mature females were present in September (48.28\%) and March (30.88\%), but lower in April (2.08\%). While, higher percentage of mature males was found in January and September but lower in August (Table 2). The oocyte sizes varied depending on gonadal development stages; Stage I (immature) $209.61 \mu \mathrm{m}$ to $592.78 \mu \mathrm{m}(447.30 \pm$ $99.42 \mu \mathrm{m}$ ), Stage II (developing) $528.37 \mu \mathrm{m}$ to $867.10 \mu \mathrm{m}$ (711.24 $\pm 63.21 \mu \mathrm{m})$, Stage III (mature) between 604.15 $\mu \mathrm{m}$ to $894.33 \mu \mathrm{m}(780.59 \pm 50.71 \mu \mathrm{m})$, stage IV (ripe) between $725.27 \mu \mathrm{m}$ to $991.81 \mu \mathrm{m}(844.09 \pm 57.59 \mu \mathrm{m})$ and stage $\mathrm{V}$ (spent) between $227.64 \mu \mathrm{m}$ to $770.82 \mu \mathrm{m}(447.38$ $\pm 139.02 \mu \mathrm{m})$ (Table 1).

The monthly GSIs of female $R$. tawarensis varied from 6.65 in April to 18.16 in September and 4.94 to 8.56 in 


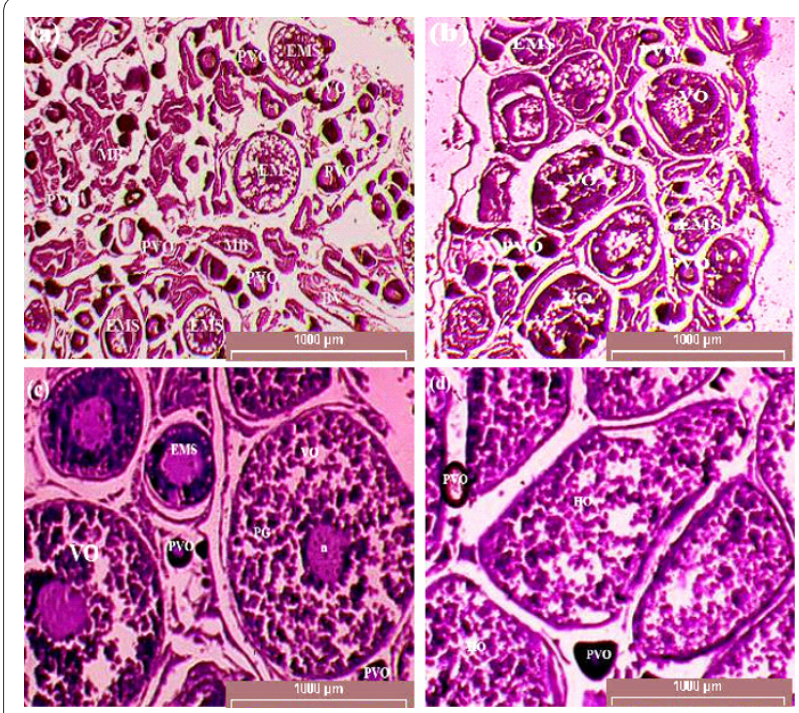

Figure 1 (a) Immature female shows many oocytes have not yet developed, (b) developing female shows many oocytes are still growing at an early maturation stage (c) mature female, (d) post ovulatory female shows hydrated oocytes. BV, blood vessel; EMS, early mature stage oocytes; $\mathrm{HO}$, hydrated oocytes; $\mathrm{MB}$, muscle bundle; PVO, previtellogenic oocytes; VO, vitellogenic oocytes; n, nucleus; PG, protein granule. male (Table 3). Female GSI was consistently higher than in male. The GSI value for both sexes begin to rise from January to March followed by a steep fall in April, and again rise sharply from July with a second peak in September before declining to resting level in November and again reaches a third peak in December (Figure 2). According to a three-year meteorological data (2004 2006) highest rainfall (with long rainy days) occurred in April, September and December, lowering drastically in January and then steadily increasing in April followed by a dry season from May to August. This largely coincided with the spawning periods.

Female GSIs which peaked in September was significantly different from other months $(P<0.05)$, then followed by March, but however, was not significantly different from August and December $(\mathrm{P}>0.05)$. Male GSIs peaked in March, but was not significantly different from September, May and January $(P>0.05)$. This indicated that the reproductive activity of $R$. tawarensis was highest in September.

\section{Size composition and sex ratio}

The monthly sample data showed that females ranged between $67.43 \mathrm{~mm}$ to $109.55 \mathrm{~mm}(89.40 \pm 5.17 \mathrm{~mm})$ in total length and $2.43 \mathrm{~g}$ to $9.40 \mathrm{~g}(5.44 \pm 0.95 \mathrm{~g})$ in weight.

Table 1: Female and male gonad developmental stages in $\boldsymbol{R}$ tawarensis and their descriptions.

\begin{tabular}{|c|c|c|c|c|c|c|}
\hline \multirow[t]{2}{*}{ Stages } & \multirow[t]{2}{*}{ Classification } & \multicolumn{2}{|c|}{ Macroscopic appearance } & \multirow[t]{2}{*}{ Oocyte size ( $\mu \mathrm{m})$} & \multicolumn{2}{|c|}{ GSI range } \\
\hline & & Testes & Ovary & & $\mathbf{F}$ & $\mathbf{M}$ \\
\hline 1 & Immature & $\begin{array}{l}\text { Small, flat, } \\
\text { translucent to } \\
\text { whitish, poorly } \\
\text { developed, } \\
\text { with reduced } \\
\text { fringes. }\end{array}$ & $\begin{array}{l}\text { Small, transparent to } \\
\text { translucent and not very } \\
\text { voluminous. Oocyte not visible } \\
\text { with naked eye. }\end{array}$ & $\begin{array}{c}209.61-592.78 \\
(447.30 \pm 99.42)^{a}\end{array}$ & $<10.9$ & $<2.0$ \\
\hline II & Develop & $\begin{array}{l}\text { Whitish with } \\
\text { voluminous } \\
\text { fringes. }\end{array}$ & $\begin{array}{l}\text { Large orange-pale, oocytes } \\
\text { may be visible through the } \\
\text { ovary tunic. }\end{array}$ & $\begin{array}{c}528.37-867.10 \\
(711.24 \pm 63.21)^{\mathrm{b}}\end{array}$ & $\begin{array}{l}11.0- \\
18.9\end{array}$ & $2.5-5.5$ \\
\hline III & Mature & $\begin{array}{l}\text { Very large, } \\
\text { firm, white in } \\
\text { colour. }\end{array}$ & $\begin{array}{l}\text { Very large occupying part of } \\
\text { the abdominal cavity. Yellow } \\
\text { oocyte turgescency. }\end{array}$ & $\begin{array}{c}604.15-894.33 \\
(780.59 \pm 50.71)^{c}\end{array}$ & $\begin{array}{l}19.0- \\
23.9\end{array}$ & $5.6-8.0$ \\
\hline IV & Ripe & $\begin{array}{l}\text { Full } \\
\text { developed, } \\
\text { turgid fringes, } \\
\text { milky-whitish } \\
\text { in colour. Milt } \\
\text { run out of the } \\
\text { fish. }\end{array}$ & $\begin{array}{l}\text { Occupying the entire } \\
\text { abdominal cavity. Ovulated } \\
\text { oocytes can be fully expelled } \\
\text { from the oviduct with gentle } \\
\text { pressure. }\end{array}$ & $\begin{array}{c}725.27-991.81 \\
(844.09 \pm 57.59)^{d}\end{array}$ & $>24.0$ & $>8.0$ \\
\hline V & Spent & $\begin{array}{l}\text { Bloody and } \\
\text { flaccid fringes. }\end{array}$ & $\begin{array}{l}\text { Flaccid, red-brown or bloody in } \\
\text { colour. Few remaining large } \\
\text { oocytes observed, and smaller } \\
\text { size oocytes may be seen. }\end{array}$ & $\begin{array}{c}227.64-770.82 \\
(447.38 \pm 139.02)^{a}\end{array}$ & $2.5-10.9$ & $1.5-3.0$ \\
\hline
\end{tabular}

\footnotetext{
*Mean oocyte size in the same column followed by a different superscript is significant different $(P<0.05)$.
} 
Table 2: Proportion of gonadal development stages according to monthly sampling $(I=$ Immature, II = Develop, III = Mature, IV = Ripe, V = Spent).

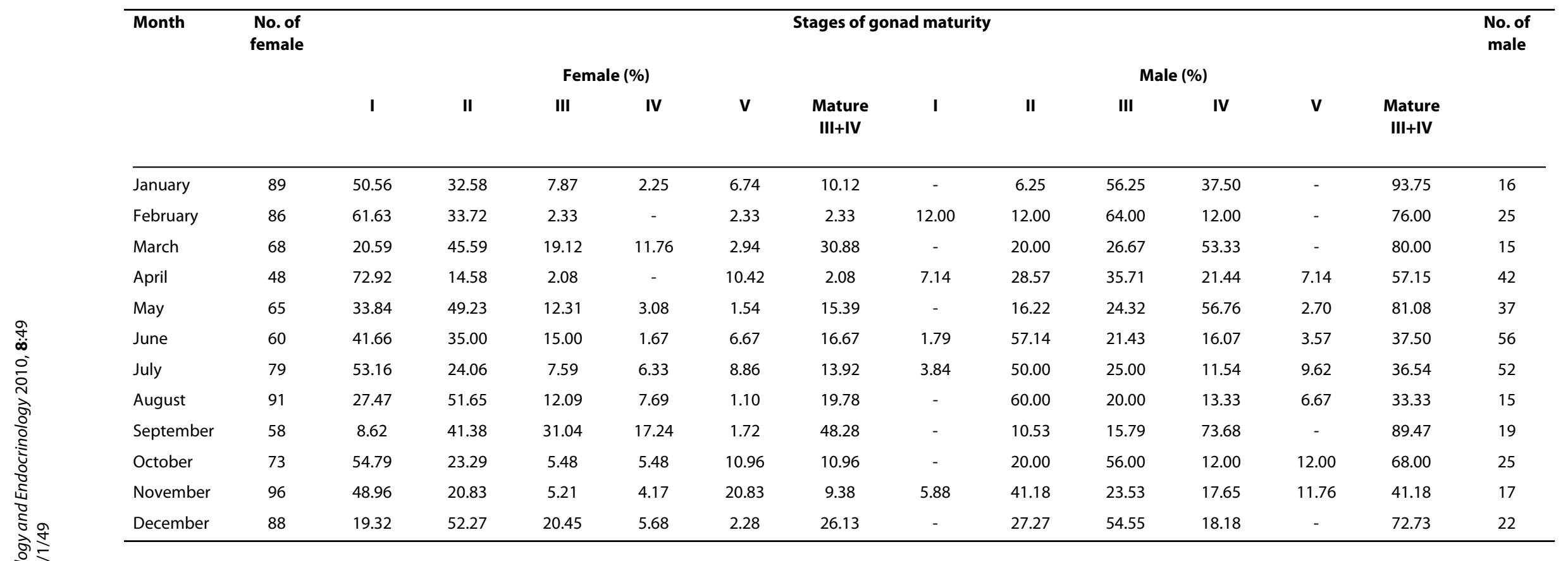




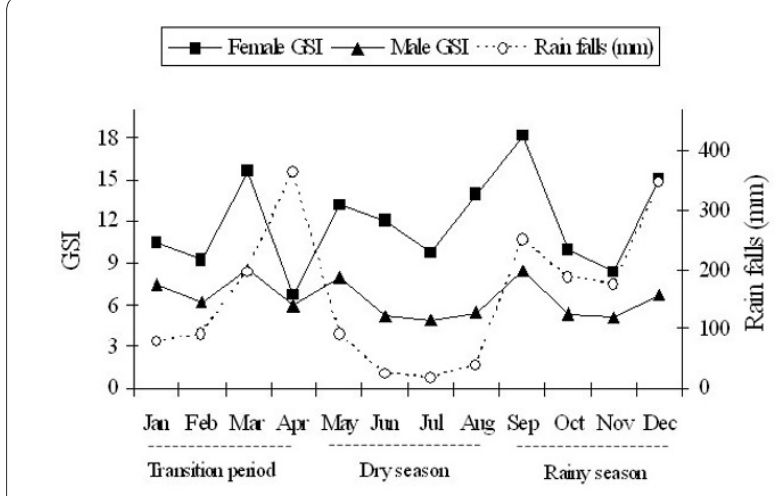

Figure 2 The GSIs showing the spawning season of $R$. tawarensis in relation to rain fall and seasons.

Males were $64.82 \mathrm{~mm}$ to $98.84 \mathrm{~mm}(81.12 \pm 5.12 \mathrm{~mm})$ in total length and $2.25 \mathrm{~g}$ to $7.32 \mathrm{~g}(4.43 \pm 0.85 \mathrm{~g})$ in weight. In addition, based on all data (including data from additional sampling in July 2009), female ranged between $62.20 \mathrm{~mm}$ to $113.31 \mathrm{~mm}$ in size $(89.39 \pm 6.74 \mathrm{~mm})$ and $2.43 \mathrm{~g}$ to $11.83 \mathrm{~g}$ weight $(5.55 \pm 1.14 \mathrm{~g})$ while male was $55.22 \mathrm{~mm}$ to $102.47 \mathrm{~mm}(80.23 \pm 8.43 \mathrm{~mm})$ in length and $1.29 \mathrm{~g}$ to $8.75 \mathrm{~g}(4.49 \pm 1.15 \mathrm{~g})$ in weight. This indicated that the females were significantly larger than males.

Mature females ranged from $70.98 \mathrm{~mm}$ to $113.31 \mathrm{~mm}$ in length and $3.52 \mathrm{~g}$ to $11.83 \mathrm{~g}$ in gonad-free body weight while males ranged from $58.06 \mathrm{~mm}$ to $102.474 \mathrm{~mm}$ in length and $2.71 \mathrm{~g}$ to $8.75 \mathrm{~g}$ in gonad-free body weight. In general, oocyte sizes and GSI increased from stage I to stage IV (immature to ripe stages) and then decreased in stage $\mathrm{V}$ (spent), being at the maximum during the period

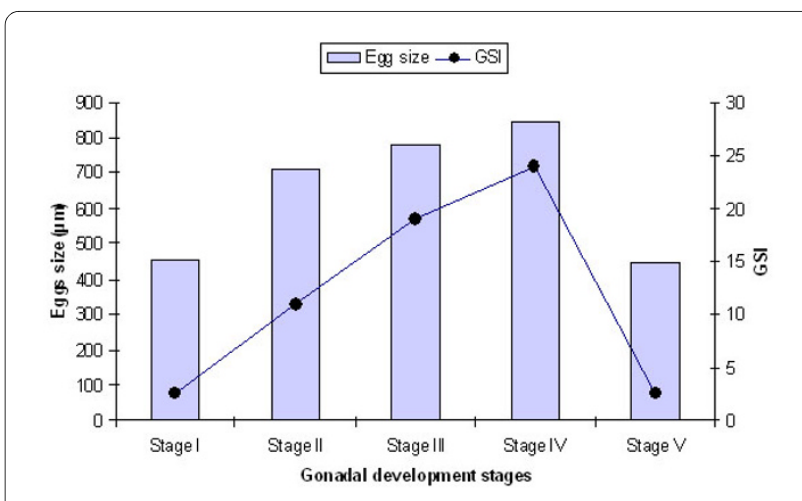

Figure 3 A plot of egg size against GSI and gonadal developmental stage of $R$. tawarensis

of peak reproductive season and declining abruptly thereafter, when the fish become spent (Figure 3). The GSI was correlated with the proportion of matured female, where GSIs increased with increasing proportion of mature fish (Figure 4).

The sex ratio (female: male) of $R$. tawarensis ranged from 1.07 in June to 6.07 in August (Table 3), with an average of $3.39 \pm 1.8$ indicating that females were dominant in the population. Although, less abundant in total, the proportion of matured male was consistently higher throughout the year (Figure 5).

\section{Discussion}

The GSI values of $R$. tawarensis for both sexes with peaks in March, September and December, presumably the likely onset of the spawning seasons largely coincided

Table 3: Gonadosomatic Index (GSI) and sex ratio according to monthly sampling

\begin{tabular}{|c|c|c|c|c|c|}
\hline \multirow[t]{2}{*}{ Months } & \multicolumn{2}{|c|}{ No. of fish examined for GSI } & \multicolumn{2}{|c|}{ GSI } & \multirow{2}{*}{$\begin{array}{c}\text { Sex ratio } \\
\text { (F/M) }\end{array}$} \\
\hline & Female & Male & Female & Male & \\
\hline January & 89 & 16 & $10.48 \pm 6.18^{b c}$ & $7.39 \pm 1.44 \mathrm{bcd}$ & 5.56 \\
\hline February & 86 & 25 & $9.21 \pm 5.08^{b}$ & $6.16 \pm 2.41^{a b}$ & 3.44 \\
\hline March & 68 & 15 & $15.56 \pm 6.88^{f}$ & $8.56 \pm 2.53^{d}$ & 4.53 \\
\hline April & 48 & 42 & $6.65 \pm 4.94^{a}$ & $5.95 \pm 2.46^{a b}$ & 1.14 \\
\hline May & 65 & 37 & $13.24 \pm 5.13^{\mathrm{de}}$ & $7.91 \pm 2.10^{c d}$ & 1.76 \\
\hline June & 60 & 56 & $11.99 \pm 5.83^{c d}$ & $5.22 \pm 3.07^{a}$ & 1.07 \\
\hline July & 79 & 52 & $9.70 \pm 7.52^{b}$ & $4.94 \pm 2.63^{a}$ & 1.52 \\
\hline August & 91 & 15 & $13.95 \pm 6.27^{\mathrm{def}}$ & $5.46 \pm 2.63^{a}$ & 6.07 \\
\hline September & 58 & 19 & $18.16 \pm 5.39 \mathrm{~g}$ & $8.44 \pm 2.18^{d}$ & 3.05 \\
\hline October & 73 & 25 & $9.96 \pm 6.63^{b c}$ & $5.30 \pm 3.97^{a}$ & 2.92 \\
\hline November & 96 & 17 & $8.38 \pm 7.12^{a b}$ & $5.14 \pm 2.41^{a}$ & 5.65 \\
\hline December & 88 & 22 & $15.08 \pm 6.00^{e f}$ & $6.68 \pm 1.82^{\mathrm{abc}}$ & 4.00 \\
\hline
\end{tabular}

${ }^{*}$ Mean of GSIs in the same column followed by a different superscript indicates significantly different $(\mathrm{P}<0.05)$. 


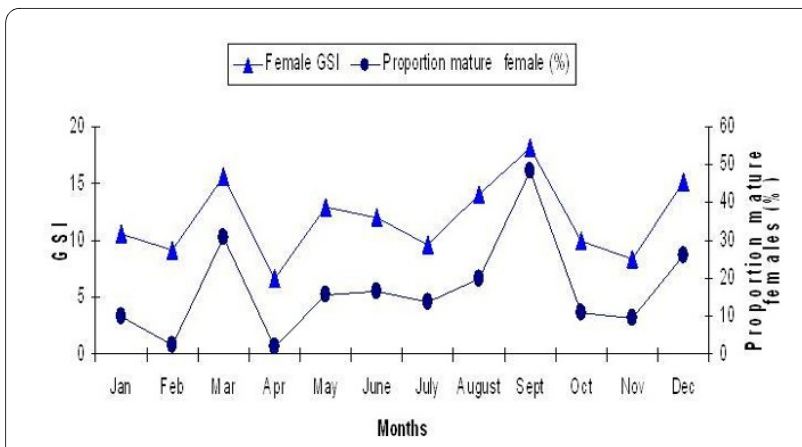

Figure 4 A plot of relationship between GSI and proportion of matured female of $R$. tawarensis.

with the rainy seasons. Our observation showed that the fish migrates from the lake to river tributaries for spawning, frequently during rainstorm in the rainy season. Its spawning season occurs twice during the rainy season i.e. early and at the end of the season. In addition during the transition period where the rain falls and the rainy days were relatively higher compared to the dry season, the fish is also triggered to spawn. According to Rainboth [20] the spawning activities of Southeast Asian cyprinids are accomplished in a variety of ways; longitudinal migration from downstream to up stream and vice versa or even laterally from the stream they inhabit into temporary flooded riparian areas or tributaries. Many studies have reported high correlation of rainy season with spawning peaks of tropical fishes associated with flooding of rivers and lakes, or the monsoons. For example $T$. thynnoides in the Chenderoh Reservoir, Malaysia spawned during the rainy season in January, August, and November when the water level was high [3]. The spawning season of African bonytongue fish in the So River in the floodplain of West Africa occurred during the wet season (May to August) as floodwaters gradually rose [21]. In addition, the reproduction in Tor putitora was

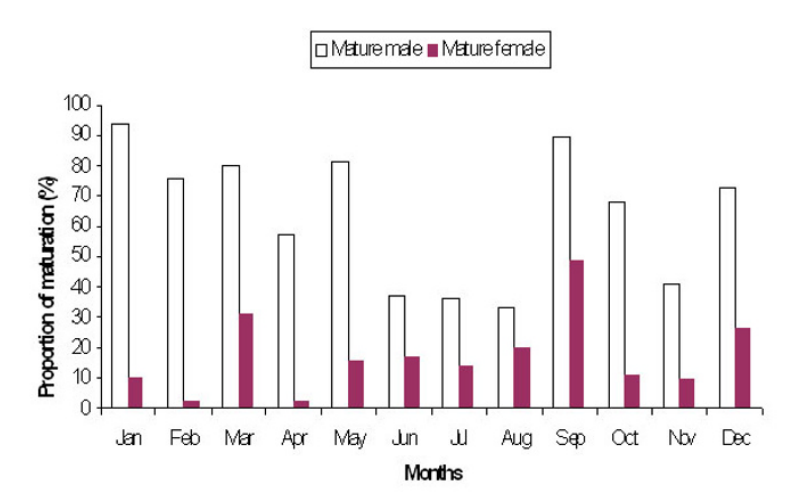

Figure 5 Comparison of sexual maturation between male and female R. tawarensis throughout the year. observed mainly in the autumn months of March to April and also in the monsoon months, from July to August. During these months, T. putitora migrated from the main river to the tributaries where it bred in the flooded waters [22]. In general, fishes in the tropics depend on rainfall to trigger the reproductive cycle as the stable temperature and photoperiod could not generate reproductive cues [10].

Typically, fish migrate upstream to spawn when the water level increases during the rainy season, to ensure that the current brings eggs and larvae into nursery areas on the floodplain further downstream. During this season the fish feed intensively in the flood zone, growing and building up fat layers for the following dry season, when the food is scarce [23]. The periodic floods provide increased available habitat and also releases nutrients that evoke blooms of phytoplankton and an increase in micro zooplanktonic food organisms for the hatchling fishes [24]. The increased water level, inundation of shallow areas, increase in water velocity and turbidity may be responsible for inducing the fish to spawn [25] especially for fishes in the flood plain areas [26]. This is also the main feeding and growing period for many tropical fishes, when they build up fat stores to carry them through the dry season [24]. In addition, in tropical zones, seasonal changes of environment are less extreme, and many fishes exhibit extended or continuous reproductive pattern [27]. This is in agreement with the moderate levels of GSI in January and February as observed in this study. Thus these add further support that the rainy season or rainfall plays an important role in reproductive period of tropical fishes.

It is highly likely that $R$. tawarensis is capable of spawning throughout the year, as mature males and females were detected throughout the year, although more abundant during certain periods with a peak season in September. A similar phenomenon was observed in $C$. pleurophthalmus [14] and Astyanax fasciatus [28] which had the potency to spawn throughout the year, with spawning peak influenced by water temperature and rainfall. Based on gonadal development and variation of oocyte size in the ovary, $R$. tawarensis can be classified as a group synchronous spawner or a fractional multiple spawners, having two or more distinct clutches of oocyte existing concurrently with each clutch at a different developmental stage. According to Redding and Patino [27], this pattern allows for multiple, distinct ovulatory events that typically follow seasonal, lunar, or diurnal cycles.

Female GSI values of $R$. tawarensis were consistently higher than in male, a phenomenon also observed in the freshwater catfish Oxydoras sifontesi and Pimelodus blochii from Venezuelan floodplains [18] and A. fasciatus 
from south-eastern Brazil [28]. The GSI is one of the main parameters used to evaluate gonadal development in fishes and this method is easier and cheaper to utilize. The high correlation of GSI with number of matured females and males could be utilised to extrapolate peak spawning season. Furthermore, the GSI and length frequency distributions provide good population-level information of reproductive performance [29].

The sex ratio of $R$. tawarensis fluctuated seasonally. This is in agreement with Nikolsky [30] who reported that the sex ratio may vary from year to year in the same population, but in most fish species it is close to one, for example in the rainbow selebensis, T. celebensis [12], Protopterus annectens [31] and Oreochromis niloticus [32]. However, the sex ratio of $R$. tawarensis showed a predominance of female, a similar trend to that reported for Tilapia mariae [33], A. fasciatus [28] and Pellonula leonensis [34]. In contrast, in Abudefduf saxatilis [35] and T. putitora [22], the number of male was higher than female.

However, the reported sex ratios may have be biased due to selectivity of fishing gear, therefore independent data from other fishing gears would be required to validate whether the samples obtained from existing gears were representative of the population [7]. Furthermore, the seasonal variation in the sex ratio observed was probably because once fertilization of eggs was completed, male possibly emigrates from spawning area towards feeding ground located in the shallow areas [32].

\section{Conclusions}

Gonadosomatic indices (GSI) of female $R$. tawarensis were highest in the months of March, September and December with the peak in September, indicating the onset of the reproductive seasons. However, matured fishes were detected throughout the year. The $R$. tawarensis was classified as a group synchronous spawner. In addition, the female was predominant in the population.

\section{Competing interests}

The authors declare that they have no competing interests.

\section{Authors' contributions}

ZAM, the author responsible for developing of the study design, data collection and analyses, data interpretation and manuscript drafting. MM, the author responsible for data collection, statistical analysis, and intellectual contents. SAMN, the author responsible for manuscript sequence alignment, language corrections and final approval of the manuscript to publish. All authors read and approved the final manuscript.

\section{Acknowledgements}

We would like to express our gratitude to the Ministry of Education Republic of Indonesia through the Directorate General of Higher Education for providing fellowship and research grant for the first author and special thanks to Universiti Sain Malaysia for providing USM-RU-PGRS Research Grant and facilities during the study. The field assistance by all members of the Aquaculture Research Group of Syiah Kuala University, Banda Aceh, Indonesia is also acknowledged.

\section{Author Details}

1School of Biological Sciences Universiti Sains Malaysia, Penang 11800 Malaysia, ${ }^{2}$ Department of Aquaculture, Coordinator of Fishery and Marine Sciences, Syiah Kuala University, Banda Aceh 23111, Indonesia, ${ }^{3}$ Centre for Marine and Coastal Studies Universiti Sains Malaysia, Malaysia and ${ }^{4}$ Department of Marine Sciences, Coordinator of Fishery and Marine Sciences, Syiah Kuala University, Banda Aceh 23111, Indonesia

Received: 10 March 2010 Accepted: 18 May 2010 Published: 18 May 2010

\section{References}

1. IUCN data base [http://www.iucnredlist.org]

2. CBSG: Conservation Assessment and Management Plan for Sumatran Threatened Species. Apple Valley, MN USA: IUCN-SSC Conservation Breeding Specialist Group; 2003:5-9.

3. Ali AB, Kadir BKA: The reproductive biology of the cyprinid, Thynnichthys thynnoides (Bleeker), in the Chenderoh Reservoir - a small tropical reservoir in Malaysia. Hydrobiologia 1996, 318:139-151.

4. Ezenwaji HMG: The breeding biology of Clarias albopunctatus Nichols \& LaMonte, 1953 in semi-intensively managed pond in the floodplain of the River Anambra, Nigeria. Ecol Freshw Fish 1998, 7:101-107.

5. Marshall CT, O'Brien L, Tomkiewiez J, Koster FW, Kraus G, Marteinsdottir G, Morgan MJ, Saborido-Ray F, Blanchard JL, Secor DH, Wright PJ, Mukhina $\mathrm{NV}$, Bjornsson $\mathrm{H}$ : Developing alternative indices of reproductive potential for use in fisheries management, case studies for stocks spanning, an information gradient. J Northw Atl Fish Sci 2003, 33:161-190.

6. Brewer SK, Rabeni CF, Papoulias DM: Comparing histology and gonadosomatic index for determining spawning condition of smallbodied riverine fishes. Ecol Freshw Fish 2008, 17:54-58.

7. Grandcourt EM, Al-Abdessalaam TZ, Francis F, Al-Shamsi AT, Hartmann SA: Reproductive biology and implications for management of the orange-spotted grouper Epinephelus coioides in the southern Arabian Gulf. J Fish Biol 2009, 74:820-841.

8. Schlosser IJ: Environmental variation, life-history attributes, and community structure in stream fishes: implications for environmenta management and assessment. Environ Manage 1990, 15:621-628.

9. Morgan MJ: Integrating reproductive biology into scientific advice for fisheries managemen. J Northw Atl Fish Sci 2008, 41:37-51.

10. Hails AJ, Abdullah Z: Reproductive biology of the tropical fish Trichogaster pectoralis (Regan). J Fish Biol 1982, 21:157-170.

11. Ali AB: Aspect of the reproductive biology of female snakehead (Channa striata Bloch) obtained from irrigated rice agro-ecosystem, Malaysia. Hydrobiologia 1999, 00:1-7.

12. Nasution $\mathrm{SH}$ : Karekteristik reproduksi ikan endemic rainbow selebensis (Telmatherina celebensis Boulenger) di Danau Towuti. J Indo Fish Res 2005, 3(2):13-18

13. Nasution SH, Sulistiono, Soedharma D, Muchsin I, Wirjoatmojo S: Kajian aspek reproduksi ikan endemic bonti-bonti (Paratherina striata) di Danau Towuti, Sulawesi Selatan. J Indo Bio 2007, 4(4):225-238.

14. Said A: Penelitian beberapa aspek biologi ikan serandang (Channa pleurophthalmus) di DAS Musi, Sumatera Selatan. Neptunus 2007, 14(1):15-23.

15. Brown-Peterson NJ, Overdtreet RM, Lotz JM, Franks JS, Burns KM: Reproductive biology of cobia, Rachycentron canadum, from coasta waters of southern United States. Fish Bull 2001, 99:15-28.

16. Tracey SR, Lyle JM, Haddon M: Reproductive biology and per-recruit analysis of striped trumpeter (Latris lineate) from Tasmania, Australia: Implication for management. Fish Res 2007, 84:358-367.

17. West $\mathrm{G}$ : Methods of assessing ovarian development in fishes: A review. Aust J Mar Freshwat Res 1990, 41:199-222.

18. Marcano D, Cardillo E, Rodriguez C, Poleo G, Gago N, Guerrero HY: Seasonal reproductive biology of two species of freshwater catfish from the Venezuelan floodplains. Gen Comp Endocrinol 2007, 153:371-377.

19. Dytham C: Choosing and using statistics. A biologist's guide (Second edition). Oxford: Blackwell Publishing: 2003. 
20. Rainboth WJ: Cyprinids of Southeast Asia: Cyprinids fishes, systematics, biology and exploitation. Edited by: Winfiled IJ, Nelson JS. London: Chapman and Hall; 1991.

21. Adite A, Winemiller KO, Fiogbe ED: Population structure and reproduction of the African bonytogue Heterotis niloticus in the So River-floodplain system (West Africa): implication for management. Ecol Freshw Fish 2006, 15:30-39.

22. Singh AK: Biological and reproductive diversity in reverie as well as lacustrine golden mahseer, Tor putitora (Hamilton 1822) in central Malayas, India. In Mahseer, the biology, culture and conservation Edited by: Siraj SS, Christianus A, Kiat NN, De Silva SS. Kuala Lumpur: Malaysian Fisheries Society; 2007:79-97.

23. Poulsen AF, Hortle KG, Valbo-Jorgensen J, Chan S, Chuon CK, Viravong S, Bouakhamvongsa K, Suntornratana U, Yoorong N, Nguyen TTT, Tran BQ: Distribution and ecology of some important riverine fish species of the Mekong River Basin. Phnom Penh: Mekong River Commission 2004:1-116.

24. Bone Q, Marshall NB, Blaxter JHS: Biology of fishes (second edition). London: Chapman and Hall; 1996.

25. Rahman AA, Moghraby Al: Breeding of Barbus bynni (Pisces, Cyprinidae) in Jebel Aulia Reservoir, Sudan. Hydrobiologia 1984, 110:319-325.

26. Winemiller KO: Feeding and reproductive biology of the currito, Hoplosternum littorale, in the Venezuelan llanos with comment on the possible function of the enlarge male pectoral spine. Environ Biol Fishes 1987, 20:219-227.

27. Redding JM, Patino R: Reproductive Physiology. In The Physiology of Fishes Edited by: Evan DH. Boca Raton, Florida: CRC Press Inc; 1993:503-534

28. Carvalho PAD, Paschoalini AL, Santos GB, Rizzo E, Bazzoli N: Reproductive biology of Astyanax fasciatus (Pisces: Characiformes) in a reservoir in southern Brazil. J Appl/chthyol 2009, 25:306-313.

29. Durham BW, Wilde GR: Asynchronous and synchronous spawning by smalleye shiner Notropis buccula from the Brazos River, Texas. Ecol Freshw Fish 2008, 17:528-541.

30. Nikolsky GV: The ecology of fishes. London: Academic Press; 1963.

31. Oniye SJ, Adebote DA, Usman SK, Makpo JK: Some aspects of the biology of Protopterus annectens (Owen) in Jachi Dam near Katsina, Katsina State, Nigeria. J Fish Aquat Sci 2006, 1(2):136-141.

32. Offem BO, Akegbejo-Samsons Y, Omoniyi IT: Biological assessment of Oreochromis niloticus (Pisces: Cichlidae: Linne, 1958) in a tropical floodplain river. Afr J Biotechnol 2007, 6(16):1966-1971.

33. Anene A, Okorie PU: Some aspect of the reproductive biology of Tilapia mariae (Boulenger, 1901) in a small lake in south-eastern Nigeria. Afr J Biotechnol 2008, 7(14):2478-2482.

34. Kingdom T, Allison ME: Aspects of the reproductive biology of Pellonula leonensis (Boulenger, 1916: Clupeidae) in the Lower Nun River, Niger Delta. Curr Res J Biol Sci 2009, 1(3):68-71.

35. Bessa E, Dias JF, deSouza AM: Rare data on a rocky shore fish reproductive biology: Sex ratio, length of first maturation and spawning period of Abudefduf saxatilis (Linnaeus, 1758) with note on Stegastes variabilis spawning period (Perciformes: Pomacentridae) in Sao Paulo, Brazil. Braz J Oceanogr 2007, 55(3):199-206.

doi: $10.1186 / 1477-7827-8-49$

Cite this article as: Muchlisin et al., Spawning seasons of Rasbora tawarensis (Pisces: Cyprinidae) in Lake Laut Tawar, Aceh Province, Indonesia Reproductive Biology and Endocrinology 2010, 8:49

\section{Submit your next manuscript to BioMed Central} and take full advantage of:

- Convenient online submission

- Thorough peer review

- No space constraints or color figure charges

- Immediate publication on acceptance

- Inclusion in PubMed, CAS, Scopus and Google Scholar

- Research which is freely available for redistribution

Submit your manuscript at www.biomedcentral.com/submit
C BioMed Central 